\title{
Wpływ wprowadzenia jednomandatowych okręgów wyborczych w wyborach samorządowych na wyniki wyborów
}

\author{
Konrad Składowski \\ Dr hab., Uniwersytet Łódzki, Wydział Prawa i Administracji, \\ Katedra Prawa Konstytucyjnego \\ http://dx.doi.org/10.18778/8088-114-3.06
}

Kodeks wyborczy uchwalony 5 stycznia 2011 r. ${ }^{1}$ wprowadził nowe zasady przeprowadzania wyborów do organów stanowiących gmin, które zostały po raz pierwszy zastosowane w wyborach samorządowych przeprowadzonych 30 listopada 2014 r. Podstawowa zmiana regulacji prawnej dotyczyła zmiany systemu wyborczego sensu stricto w wyborach radnych w gminach powyżej 20 tys. mieszkańców. Wcześniej obowiązujące przepisy prawa wyborczego przewidywały, iż wyboru radnych w tych jednostkach samorządu terytorialnego dokonuje się przy zastosowaniu zasady proporcjonalności. Kodeks wyborczy wprowadził regułę, że za wyjątkiem rad miejskich w miastach na prawach powiatu radni będą wybierani według reguły większości względnej w jednomandatowych okręgach wyborczych (art. 415 i art. $418 \$ 1$ k.w.). Konsekwencją tej decyzji prawodawcy było wprowadzenie zasady, że komitet wyborczy w każdym okręgu wyborczym może zgłosić tylko jednego kandydata na radnego (art. $425 \$ 1$ i $\$ 2$ pkt 1 k.w.).

Zmiana systemu wyborczego z proporcjonalnego na większościowy wymusiła liczną zmianę przepisów prawa wyborczego. Do najważniejszych kwestii w tym zakresie należą zagadnienia związane $\mathrm{z}$ : podziałem jednostek samorządu terytorialnego na okręgi wyborcze, zasadami zgłaszania kandydatów, większym zróżnicowaniem rodzajów komitetów wyborczych, zasadami prowadzenia kampanii wyborczej czy chociażby zmianą reguł dotyczących finansowania wyborów, czy limitów wydatków. Kwestie te, choćby częściowo, zostały już dostrzeżone w literaturze

1 Dz.U. z 2011, Nr 21, poz. 112 z późn. zm. 
przedmiotu ${ }^{2}$. Wszystkie $\mathrm{z}$ wymienionych zagadnień mogą stanowić interesujący obszar dla analiz. Konkurowanie w wyborach do rad gmin komitetów o charakterze ogólnokrajowym z komitetami lokalnymi oraz pojedynczymi kandydatami niezależnymi pozwala stawiać pytania dotyczące równości podmiotów uczestniczących w wyborach w szczególności z punktu widzenia zasady równości szans. Wśród wymienionych problemów szczególnie interesująco prezentują się dwa.

Pierwszy wiąże się z wprowadzeniem nowego podziału na okręgi wyborcze $\mathrm{w}$ jednostkach samorządu terytorialnego. Zagadnienie to wydaje się być szczególnie ciekawe z dwóch powodów. Po pierwsze, przez przyjęcie przez ustawodawcę bardzo dużego dopuszczalnego odchylenia od jednolitej normy przedstawicielstwa. Otóż art. $419 \$ 2$ i 3 k.w. pozwala przy tworzeniu okręgów wyborczych na odstępstwa od jednolitej normy przedstawicielstwa w granicach od 50\% do $149 \%$. Oznacza to, że na terenie gminy mogą występować obok siebie okręgi wyborcze, których liczba mieszkańców nawet trzykrotnie może różnić się od liczby mieszkańców pozostałych okręgów, co stawia pod znakiem zapytania zachowanie zasady równości materialnej wyborów. Warto zaznaczyć, iż w demokratycznych systemach wyborczych zaleca się stosowanie bardziej rygorystycznych wymogów dotyczących tworzenia okręgów wyborczych ${ }^{3}$. Na marginesie warto podkreślić, że obowiązujące w Polsce w latach 19901998 przepisy regulujące wybory do rad gmin pozwalały z uzasadnionych względów na odstępstwa od jednolitej normy przedstawicielstwa na poziomie $20 \%{ }^{4}$. Po drugie, zadanie stworzenia nowej struktury okręgów wyborczych ustawodawca powierzył radom gmin ${ }^{5}$. Radni zaś są żywotnie zainteresowani takim podziałem na okręgi wyborcze, który istotnie

2 P. Bała, Problematyka prekampanii w wyborach samorzadowych na szczeblu gminy, „Przegląd Sejmowy” 2015, nr 3 (128), s. 57-66; G.Kryszeń, Problematyka zgłaszania kandydatów w świetle kodeksu wyborczego, [w:] Kodeks wyborczy. Wstępna ocena, red. K. Skotnicki, Warszawa 2011, s. 159-193; J. Szymanek, Prawna regulacja komitetów wyborczych w kodeksie wyborczym, [w:] Kodeks wyborczy. Wstępna ocena, red. K.Skotnicki, Warszawa 2011, s. 71-111.

3 Dokument ten wskazuje, że odstępstwo od normy przedstawicielstwa nie powinno przekraczać $15 \%$. Kodeks Dobrej Praktyki w Sprawach Wyborczych. Wytyczne i Raport wyjaśniający, przyjęte przez Europejską Komisję dla Demokracji przez Prawo (Komisję Wenecką) Rady Europy w lipcu 2002 r. www.pkw.gov.pl (dostęp 12.10.2015 r.).

4 Art. 13 ustawy z dnia 8 marca 1990 r. - Ordynacja wyborcza do rad gmin (Dz.U. z 1990 r. Nr 16, poz. 96).

5 Stosownie do art. $419 \S 2$ i 3 k.w. podziat gminy na okręgi wyborcze, ich granice i numery ustala w drodze uchwały rada gminy (rada miejska) na wniosek wójta (burmistrza, prezydenta miasta). W myśl art. $419 \S 4$ k.w. uchwałę rady gminy w sprawie podziału gminy na okręgi wyborcze ogłasza się w wojewódzkim dzienniku urzędowym oraz podaje się do publicznej wiadomości w sposób zwyczajowo przyjęty w danej gminie, a także przekazuje niezwłocznie wojewodzie i komisarzowi wyborczemu. 
zwiększy ich szanse na sukces wyborczy. Korelacja tych dwóch czynników może prowadzić do tego, że struktura okręgów wyborczych nie będzie realizować zasady równości materialnej ${ }^{6}$. Co więcej, istnieje, także zagrożenie, że proces wytyczania granic okręgów wyborczych będzie w dużym stopniu poddany zjawisku geografii wyborczej. Oczywiście należyta ocena tej kwestii wymaga przeprowadzenia szczegółowych i bardzo szeroko zakrojonych badań empirycznych. Bez ich przeprowadzenia nie sposób wyciągnąć jednoznacznych wniosków, czy zasada równości materialnej wyborów jest właściwie realizowana w wyborach samorządowych. O ile badania takie można przeprowadzić w odniesieniu do wyborów parlamentarnych, w których liczba okręgów wyborczych nie przekracza 100 jak np. w wyborach do Senatu ${ }^{7}$ o tyle podobny zabieg w odniesieniu do wyborów samorządowych jest oczywiście możliwy, lecz znacznie przekroczyłby rozmiary przyjęte dla tego opracowania. Przede wszystkim $\mathrm{z}$ tego powodu, że wymagałoby to przebadania ponad 170 gmin z punktu widzenia struktury występujących tam okręgów wyborczych. Wziąwszy pod uwagę, że te 170 gmin należy pomnożyć przez 21 lub 23, gdyż tylu radnych wybiera się w gminach objętych badaniem, osiągamy liczbę, znacznie przekraczającą 3,5 tysiąca okręgów wyborczych. Tak więc jest to niezwykle interesujące zagadnienie, który dla bliższej analizy wymaga bardzo rozbudowanych badań.

Drugi ciekawy problem dotyczy analizy wpływu przyjęcia nowego systemu wyborczego sensu stricto na podział mandatów. W swych rozważaniach skoncentruję się na tej właśnie kwestii, a więc na analizie wpływu nowego systemu wyborczego na podział mandatów w wyborach do rad gmin i miast, w których system proporcjonalny został zastąpiony systemem większościowym.

Badaniem objęte zostały 173 gminy, w których w wyborach do rad nastąpiła zmiana systemu wyborczego. Poza obszarem czynionych rozważań pozostawiam więc te jednostki samorządu terytorialnego, których nie dotknęła zmiana systemu podziału mandatów, czyli miasta na prawach powiatu oraz gminy poniżej 20 tys. mieszkańców. Uznałem, że jest to szczególnie interesująca kwestia badawcza, w szczególności w kontekście ożywionej od momentu kampanii na urząd Prezydenta RP debaty na temat jednomandatowych okręgów wyborczych. Analiza rozstrzygnięć wyborczych, jakie zapadły w wyborach samorządowych w 2014 r. może stanowić ważny element tej dyskusji.

6 Na problem ten zwrócono już uwagę w literaturze. Patrz: A. Cebula, Materialna równość wyborów do rad gmin niebędących miastami na prawach powiatu, „Państwo i Prawo" 2015, nr 2, s. 65-69.

7 Patrz: K .Składowski, Zasada równości wyborów a wybory do Senatu w kodeksie wyborczym, [w:] Kodeks wyborczy. Wstępna ocena, red. K. Skotnicki, Warszawa 2011, s. 286-291. 
Pierwszym problemem, który został poddany analizie, była ocena wpływu zmiany systemu wyborczego na liczbę zarejestrowanych komitetów wyborczych i zgłoszonych kandydatów. W badanych gminach liczba komitetów wyborczych, partii politycznych o zasięgu ogólnokrajowym, lokalnych komitetów wyborczych i komitetów pojedynczych, niezależnych kandydatów była bardzo zróżnicowana ${ }^{8}$. Największa liczba zarejestrowanych komitetów wyborczych wystąpiła w Lęborku i Gryfinie i wynosiła 19, z tym, że na tak znaczną liczbę zarejestrowanych komitetów wpływ miało przede wszystkim to, że w miastach tych zarejestrowała się największa liczba kandydatów niezależnych, gdyż aż $11 \mathrm{w}$ Legionowie i 7 w Gryfinie. Zresztą w większej części pozostałych gmin o dużej liczbie zarejestrowanych komitetów sytuacja jest podobna. To znaczy, że na liczbę zarejestrowanych komitetów wpływa istotnie liczba kandydatów niezależnych. W badanych gminach liczba komitetów biorących udział w wyborach wahała się od 2 do 19. Najczęściej jednakże mieściła się w przedziale między 9 a 11. W 77 gminach ze 172, czyli w blisko połowie badanych, liczba zgłoszonych komitetów mieściła się w tym przedziale. Przeprowadzona analiza nie pozwala na sformułowanie korelacji między wielkością gminy (z punktu widzenia liczby mieszkańców) a liczbą zgłoszonych komitetów wyborczych. Gminy, w których zarejestrowana została największa jak i najmniejsza liczba komitetów to zasadniczo gminy między 20 i 35 tys. mieszkańców. W odniesieniu do kwestii liczby zgłoszonych komitetów wyborczych ciekawy jest przypadek gminy Lubliniec gdzie zostały zgłoszone jedynie dwa komitety wyborcze. Oba były to komitety lokalne związane z osobami kandydatów na burmistrza tej gminy. Tym samym o 21 mandatów ubiegało się jedynie 42 kandydatów. Co ciekawe w poprzednich wyborach lokalnych przeprowadzonych w 2010 r. w Lublińcu startowało w wyborach 7 komitetów wyborczych z czego 4 lokalne, które zgłosiły łącznie 212 kandydatów na radnych. Wydaje się, że w Lublińcu lokalni działacze polityczni właściwie odczytali, że wprowadzenie jednomandatowych okręgów wyborczych jest korzystne dla najsilniejszych ugrupowań i dokonali konsolidacji lokalnej sceny politycznej dla jak najefektywniejszego wykorzystania efektu ordynacji większościowej. W Radzie miasta wyłonionej w wyborach w 2010 r. zasiadali przedstawiciele 6 komitetów wyborczych, obecnie jedynie 2. Komitet burmistrza miasta w 2010 r. zdobył 7 mandatów i nie posiadał

8 W tekście posługuję się konsekwentnie pojęciem „niezależny kandydat” na oznaczenie tych kandydatów, którzy zgłaszali swój komitet wyborczy, startując tylko w jednym okręgu wyborczym. Zdaję sobie rzecz jasna sprawę z faktu, iż na listach innych komitetów, które wystawiały kandydatów w więcej niż jednym okręgu wyborczym, także znajdowali się kandydaci niezależni, lecz z braku lepszego określenia termin „niezależny kandydat” zarezerwowałem dla komitetów, które zarejestrowały się tylko w jednym mieście lub gminie i wystawiły tylko jednego kandydata. 
samodzielnie większości w radzie miasta. W wyborach z 2014 r. jego komitet wprowadził do rady 13 radnych. W wyborach w 2010 r. komitet ten uzyskał $25,75 \%$ poparcia, a w wyborach w 2014 r. 55,46\% poparcia. Można jednakże przypuszczać, że poziom uzyskana poparcia w wyborach wynikał z faktu, że wyborcy nie mieli szerszej oferty i zmuszeni byli dokonywać wyboru spośród tylko dwóch komitetów wyborczych. Frekwencja w 2014 r. wyniosła 34,49\% natomiast w 2010 r. 45,9\%. Jak widać, między kolejnymi wyborami nastąpił bardzo duży spadek frekwencji. Zdiagnozowanie powodów tego stanu rzeczy przekracza zakres tej pracy i jest zadaniem dla socjologów, a nie prawnika. Możliwe jednakże jest i to, że zacięta rywalizacja polityczna między dwoma środowiskami polityczno-społecznymi na terenie tej gminy doprowadziła do takiej polaryzacji, że inne środowiska oraz kandydaci niezależni uznali, że nie mają szans na zdobycie mandatu i nie wzięli udziału w głosowaniu, co mogło wpłynąć na zniechęcenie części wyborców do udziału w wyborach ze względu na ich przekonanie o braku satysfakcjonującej ich oferty wyborczej. W każdym razie przypadek ten wskazuje, że oczekiwane przez zwolenników jednomandatowych okręgów wyborczych efekty zastosowania systemu mogą istotnie odbiegać od ich oczekiwań.

Porównując liczbę zgłoszonych komitetów w wyborach samorządowych w 2010 r. i 2014 r., można zaobserwować niewielki wzrost liczby zgłoszonych komitetów wyborczych w 2010 r. liczba ta wyniosła 12 511, natomiast w 2014 r. 12 549. Jest to wzrost poniżej 1\%, co pozwala postawić tezę, że zmiana systemu wyborczego w niewielkim stopniu, a być może w ogóle, wpłynęła na zwiększenie liczby zgłoszonych komitetów wyborczych. Teza ta wydaje się być tym bardziej prawdopodobna, jeśli weźmie się pod uwagę fakt, iż w wyborach samorządowych w 2006 r. liczba zarejestrowanych komitetów wyborczych wyniosła 13207 a w 2002 r. 27704.

W prawie wszystkich badanych gminach liczba lokalnych komitetów przewyższała liczbę komitetów zgłoszonych przez partie polityczne. Tylko w trzech gminach sytuacja była odwrotna. Były to: Chrzanów (4 ogólnokrajowe i 3 lokalne komitety), Świecie (4 ogólnokrajowe i 3 lokalne komitety), Włoszczowa (6 ogólnokrajowych i 5 lokalnych komitetów). Jedynie w czterech gminach partie polityczne w ogóle nie zgłosiły swoich kandydatów. Były to: Gostynin (3 lokalne komitety i 5 kandydatów niezależnych), Racibórz (5 lokalnych komitetów i 5 kandydatów niezależnych), Jawor (5 lokalnych komitetów i 1 niezależny kandydat) oraz wspomniany już Lubliniec (2 lokalne komitety). Przy czym tylko w 10 gminach swoich kandydatów zarejestrowało więcej niż 4 komitety o zasięgu ogólnokrajowym. Warto jednakże pamiętać, że część partii politycznych w niektórych gminach nie decydowała się na zgłaszanie samodzielnie komitetów wyborczych, lecz na udzielenie poparcia jakiejś lokalnej inicjatywie 
politycznej. Warto też zwrócić uwagę na fakt, że w województwie mazowieckim powstał komitet regionalny, który zgłosił swoich kandydatów na obszarze kilku gmin, chociaż nie w każdej gminie Mazowiecka Wspólnota Samorządowa zgłaszała kandydatów we wszystkich okręgach wyborczych. W jednej z gmin zarejestrowała tylko jednego kandydata. Tym niemniej w wielu miejscach zdobyła mandaty.

Kandydaci wystawieni w wyborach przez komitety partii politycznych o zasięgu ogólnokrajowym zdobyli w badanych gminach łącznie 1204 mandaty, natomiast kandydaci komitetów lokalnych 2436 (w tym 81 kandydaci niezależni). Jeśli pominąć fakt, że niekiedy lokalne komitety są ściśle związane z ogólnokrajowymi partiami politycznymi, to prawie dwukrotnie większa liczba mandatów jaką zdobyły w minionych wyborach samorządowych wskazuje, że w lokalnych społecznościach umacniają się środowiska społeczno-polityczne, które nie znajdują oparcia w strukturach partyjnych. Nie jest to jednak zjawisko nowe i w związku z tym nie należy go łączyć ze zmianą systemu wyborczego. Sytuacja ta jest zresztą widoczna już od dłuższego czasu i jak sądzę walnie przyczyniło się do tego wprowadzenie zasady bezpośrednich wyborów prezydentów, burmistrzów i wójtów. Bowiem duża część komitetów lokalnych, to komitety, które w wyborach samorządowych oprócz kandydatów na radnych zgłaszały także kandydatów na prezydenta lub burmistrza. Zresztą najwięcej mandatów, spośród tych zdobytych przez komitety lokalne, to mandaty zdobyte przez te komitety, które odniosły sukces w wyborach organów wykonawczych gmin lub których kandydaci przechodzili do drugiej tury wyborów prezydentów lub burmistrzów. Komitety wyborcze, które odniosły sukces w wyborach prezydentów i burmistrzów z reguły osiągały również dobry, a niekiedy nawet bardzo dobry, wynik w wyborach do rad gmin. Na 3682 mandaty, które były do obsadzenia w omawianych wyborach, 1319 mandaty zdobyły wspomniane komitety. Przy czym należy podkreślić, że wśród tych komitetów były także komitety ogólnokrajowych partii politycznych.

W wielu miastach komitety, który wygrały wybory prezydenckie wygrywały także wybory do rad gmin, w niektórych przypadkach osiągając większość bezwzględną, a bardzo często uzyskując tak znaczącą liczbę mandatów, że zbudowanie koalicji większościowej nie nastręczało większych trudności. W 80 spośród 173 przeanalizowanych gmin jeden komitet wyborczy spośród uczestniczących w wyborach zdobył większość mandatów w radzie gminy. Przy czym w 70 przypadkach były to komitety wyborcze, które wygrywały wybory na urząd prezydenta lub burmistrza9

9 Przypadki, gdy komitet prezydenta lub burmistrza nie zdobył żadnego mandatu lub ich znikomą liczbę (1 lub 2) także miały miejsce w wyborach w 2014 r., lecz było to zjawisko sporadyczne. Dotyczyło to takich gmin jak Gorlice czy Nowy Targ. 
W 8 przypadkach zwycięstwo to było wręcz całkowite, gdyż wspomniane komitety zdobywały od 90 do 100\% mandatów. Co istotne, sukces ten wynikał nie tylko ze skali udzielonego przez wyborców poparcia dla kandydatów rekomendowanych przez prezydenta lub burmistrza gminy, lecz także z logiki systemu większościowego, który bezwzględnie faworyzuje najsilniejszy komitet wyborczy. Szczególnie w sytuacji, gdy konkuruje z nim kilka innych komitetów, a nie jeden silny konkurent. Miasta w, których doszło do takiej sytuacji, wskazane zostały w tabeli 1 .

\begin{tabular}{|l|c|c|c|c|}
\hline \multicolumn{1}{|c|}{ Gmina } & I.m.w g. & I.z.m. & \% poparcia & l.z.k. \\
\hline Kutno & 21 & 21 & 38,66 & 10 \\
\hline Lubin & 22 & 23 & 55,05 & 12 \\
\hline Nowa Sól & 19 & 21 & 52,97 & 9 \\
\hline Stalowa Wola & 19 & 21 & 37,19 & 9 \\
\hline Tarnowskie góry & 21 & 23 & 46,99 & 6 \\
\hline Tomaszów Maz. & 21 & 23 & 34,21 & 8 \\
\hline Trzebnica & 20 & 21 & 55,11 & 7 \\
\hline Września & 19 & 21 & 38,66 & 7 \\
\hline
\end{tabular}

Tabela 1. Miasta, w których komitety wyborcze uzyskały ponad 90\% mandatów w radach miast

l.m.w.g. - liczba mandatów do obsadzenia w wyborach do rady miasta l.z.m. - liczba zdobytych mandatów prze jeden komitet l.z.k. - liczba zgłoszonych komitetów wyborczych w gminie

Jak widać $\mathrm{z}$ przedstawionych danych, aż w czterech gminach na osiem uzyskanie ponad $90 \%$ mandatów do rady miasta było możliwe mimo poparcia dla kandydatów komitetu nie przekraczającego 40\%. Ocenę rozstrzygnięć wyborczych, które zapadły w tych gminach warto porównać z wynikami wyborów, które miały miejsce w 2010 r., gdy obowiązywał w nich inny system wyborczy. W większości analizowanych gmin zwycięstwo w wyborach prezydenckich odnieśli ci sami kandydaci, którzy wygrali wybory w 2014 r. Jedynie w Tomaszowie Mazowieckim i Stalowej Woli dotychczasowi prezydenci ponieśli porażki. W obu tych miastach wybory w II turach wygrali kandydaci Prawa i Sprawiedliwości. Jednakże ich zwycięstwo nie jest aż tak dużym zaskoczeniem, gdyż w obu tych miastach poparcie dla tej partii w kolejnych wyborach utrzymuje się na wysokim poziomie. W wyborach do rad gmin Tomaszowa Mazowieckiego i Stalowej Woli przeprowadzonych w 2010 r. najwięcej głosów poparcia i najwięcej mandatów zdobyły listy Prawa i Sprawiedliwości. Można więc uznać, że spektakularne sukcesy w wyborach do rad gmin w sześciu z pośród ośmiu omawianych gmin są pochodną wysokiej oceny jaką wyborcy wystawili dotychczasowo urzędującym prezydentom i burmistrzom. Jest 
to tym bardziej uzasadnione, że prawie wszyscy odnieśli zwycięstwo już w I turze wyborów. Wyjątkiem w tej mierze jest gmina Tarnowskie Góry, w której miała miejsce druga tura wyborów. Drugie tury odbyły się także w miastach, w których nastąpiła zmiana władzy wykonawczej gminy czyli w Tomaszowie Mazowieckim i Stalowej Woli. Warto jednakże pamiętać, że wybory rady nie są tym samym co wybory prezydenta miasta, choćby ze względu na fakt, że odbywają się w mniejszych okręgach wyborczych lecz także ze względu na odmienne zadanie jakie ustawodawca stawia przed tymi organami jednostek samorządu terytorialnego. W wyborach w 2010 r. w wyborach do rad gmin największą liczbę mandatów zdobyły te same komitety wyborcze, które odniosły tak spektakularny sukces w wyborach w 2014 r. Jednakże skala tego zwycięstwa była zdecydowanie mniejsza w Kutnie (11 mandatów), Lubinie (16 mandatów), Trzebnicy (11 mandatów) i Nowej Soli (13 mandatów). Komitety prezydentów uzyskały wprawdzie większość w radach gmin lecz skala zwycięstwa nie była tak przytłaczająca jak w 2014 r., co pozwoliło innym komitetom wyborczym także na wprowadzenie swoich przedstawicieli do rady. Warto porównać procentowe poparcie, jakie uzyskali łącznie kandydaci reprezentujący wskazane komitety w wyborach do rad gmin w 2010 i 2014 r. W większości analizowanych przypadków komitety wyborcze w wyborach w 2014 r. zwiększyły poziom swojego poparcia w porównaniu do roku 2010. Jednakże wzrost ten nie przyniósłby takiego sukcesu gdyby wybory przeprowadzone zostały według ordynacji proporcjonalnej. Jedynie w Kutnie poparcie dla komitetu prezydenta spadło. W 2010 r. wyniosło ono 44,72\% a w 2014 r. 38,66\%. Przypadek ten wyraźnie wskazuje na pewne „ryzykowne” z punktu widzenia reprezentatywności wybieranego organu konsekwencje systemu większościowego. Otóż Komitet Wyborczy Wyborców Zbigniewa Burzyńskiego w 2010 r. przy blisko 45\% poparciu zdobył 11 mandatów a w 2014 r. przy poparciu o 6pkt. proc. niższym - 21 mandatów. Jednocześnie w 2010 r. komitet wyborczy PiS przy 15\% poparcia uzyskał 4 mandaty a w roku 2014 r. 21-procentowe poparcie nie dało PiS żadnego przedstawiciela w radzie gminy. Z punktu widzenia skuteczności sprawowania władzy różnice występujące w rozstrzygnięciach wyborczych w analizowanych przypadkach nie są aż tak spektakularne. Komitety „prezydentów” albo osiągały samodzielnie większość w radzie gminy, albo uzyskiwały tyle mandatów, że większość tę mogły łatwo zbudować. Jednakże z punktu widzenia reprezentatywności wybieranego organu opisana sytuacja rodzi poważne wątpliwości. Tym bardziej, że rada gminy winna stanowić, w większym stopniu, niż ma to miejsce w przypadku parlamentu, jak najwierniejsze odzwierciedlenie zróżnicowanych interesów lokalnych. Szczególnie, że działanie organu wykonawczego gminy nie jest tak ściśle uzależnione od posiadania większości $\mathrm{w}$ radzie, jak skuteczne funkcjonowanie rządu związane jest $\mathrm{z}$ posiadaniem większości parlamentarnej. 
To zaburzenie reprezentatywności rad gmin wybieranych w wyborach większościowych ilustrują także przykłady gmin, w których komitety prezydentów lub burmistrzów uzyskały większość w radzie gminy przy stosunkowo niewysokim procentowym poparciu. Przykłady takich sytuacji zamieszczone zostały w tabeli 2 .

\begin{tabular}{|l|c|c|c|c|}
\hline \multicolumn{1}{|c|}{ Gmina } & I.m.w g. & l.z.m. & \% poparcia & I.z.k. \\
\hline Bełchatów & 23 & 15 & 27,78 & 10 \\
\hline Kędzierzyn Koźle & 21 & 13 & 17,21 & 15 \\
\hline Mielec & 21 & 13 & 24,98 & 11 \\
\hline Myszków & 21 & 11 & 27,65 & 10 \\
\hline Oleśnica & 21 & 11 & 24,98 & 9 \\
\hline Piaseczno & 23 & 12 & 23,72 & 14 \\
\hline Staszów & 21 & 11 & 26,70 & 14 \\
\hline Wyszków & 21 & 12 & 26,23 & 13 \\
\hline
\end{tabular}

Tabela 2. Gminy, w których komitety wyborcze prezydentów lub burmistrzów gmin zdobyły większość w radzie gminy, zdobywając poparcie nie przekraczające 30\% ważnie oddanych głosów. I.m.w.g. - liczba mandatów do obsadzenia w radzie gminy l.z.m. - liczba zdobytych mandatów przez komitet prezydenta lub burmistrza l.z.k. - liczba zgłoszonych komitetów wyborczych w gminie

Na pierwszy rzut oka można by uznać, że wpływ na takie rozstrzygnięcia wyborcze miał fakt, że we wskazanych gminach zarejestrowanych zostało wiele komitetów wyborczych. Jednakże jeśli weźmiemy pod uwagę, że w badanych gminach o najwyższej liczbie zgłoszonych komitetów wielu było kandydatów niezależnych to, okaże się, że w gminach tych liczba zarejestrowanych komitetów wyborczych odpowiadała średniej krajowej, czyli między 9 a 11, a w niektórych przypadkach była znacznie poniżej tej średniej jak choćby w Oleśnicy (4 komitety, 5 niezależnych) czy Mielcu (5 komitetów, 6 niezależnych). Warto ponownie porównać wyniki wyborów i poziom procentowego poparcia dla zwycięskich komitetów wyborczych w wyborach w 2010 i 2014 r.

\begin{tabular}{|l|c|c|c|c|c|}
\hline \multirow{2}{*}{ Gmina } & & 2014 & 2014 & 2010 & 2010 \\
\cline { 2 - 6 } & I.m.w g. & I.z.m. & \% poparcia & I.z.m & \% poparcia \\
\hline Bełchatów & 23 & 15 & 27,78 & 8 & 27,45 \\
\hline Kędzierzyn-Koźle & 23 & 13 & 17,21 & 8 & 23,56 \\
\hline Mielec & 21 & 13 & 24,98 & 7 & 24,49 \\
\hline Myszków & 21 & 11 & 27,65 & 7 & 21,1 \\
\hline Oleśnica & 21 & 11 & 24,98 & 7 & 27,56 \\
\hline
\end{tabular}




\begin{tabular}{|l|c|c|c|c|c|}
\hline \multirow{2}{*}{ Gmina } & & 2014 & 2014 & 2010 & 2010 \\
\cline { 2 - 6 } & I.m.w g. & I.z.m. & \% poparcia & l.z.m & \% poparcia \\
\hline Piaseczno & 23 & 12 & 23,72 & 10 & 31,82 \\
\hline Staszów & 21 & 11 & 26,7 & 7 & 25,9 \\
\hline Wyszków & 21 & 12 & 26,23 & 7 & 28,03 \\
\hline
\end{tabular}

Tabela 3. Porównanie liczby zdobytych mandatów i poziomu procentowego poparcia w wyborach w 2010 i 2014 r.

I.m.w.g. - liczba mandatów do obsadzenia w radzie gminy

I.z.m. - liczba zdobytych mandatów przez komitet prezydenta lub burmistrza

l.z.k. - liczba zgłoszonych komitetów wyborczych w gminie

Jak widać $\mathrm{z}$ danych umieszczonych $\mathrm{w}$ tabeli 3, poziom procentowego poparcia dla zwycięskich komitetów wyborczych w wyborach w 2010 i 2014 r. zasadniczo nie odbiega znacząco od siebie. Wyjątek w tej mierze stanowią gminy Piaseczno i Kędzierzyn-Koźle, w których poparcie dla zwycięskiego w obu wyborach komitetu Platformy Obywatelskiej spadło o 8 pkt. proc. w Piasecznie i o prawie 6 pkt. proc. w Kędzierzynie-Koźlu. Odnotować należy też wzrost poparcia o 6 pkt. proc. dla lokalnego komitetu w Myszkowie. W pozostałych gminach różnice $\mathrm{w}$ poziomie procentowego poparcia oscylują w granicach 2 pkt. proc. Jednakże przy zbliżonym poziomie poparcia zwycięskie komitety $\mathrm{w}$ porównywanych wyborach zdobyły zasadniczo różną liczbę mandatów. Przede wszystkim $\mathrm{w}$ żadnym $\mathrm{z}$ badanych miast $\mathrm{w}$ wyborach $\mathrm{w} 2010 \mathrm{r}$. zwycięskie komitety nie uzyskały większości w radach gmin, podczas gdy w 2014 r. każdy zapewnił sobie większość. Najbardziej znaczące w tej mierze są przykłady Bełchatowa i Piaseczna. W Bełchatowie w 2010 r. lokalny komitet wyborców „Plus”, zdobywając 27,45\% poparcia, uzyskał 8 mandatów. Natomiast w $2014 \mathrm{r}$. komitet PiS, notując niemal identyczne poparcie jak „Plus” cztery lata wcześniej czyli 27,78\%, zdobył aż 15 mandatów, a więc prawie dwa razy więcej. Notabene lokalny komitet „Plus” w 2014 r. zdobył 20,75\% głosów, dzięki którym wprowadził do rady miasta 6 radnych. Podobnie jaskrawy przykład miał miejsce w Piasecznie. Mimo że w mieście poparcie dla Platformy Obywatelskiej w wyborach w 2014 r. spadło o 8 pkt. proc. w stosunku do wyborów z 2010 r., liczba zdobytych mandatów zwiększyła się o 2, dając tej partii bezwzględną większość w radzie miasta. Równie interesująco przedstawia się kazus Kędzierzyna-Koźla. W wyborach w 2014 r. 13 mandatów zdobyła Platforma Obywatelska, uzyskując bezwzględną większość w radzie gminy. Sukces ten partia uzyskała zdobywając zaledwie 17,21\% głosów. Konkurujące z nią listy wyborcze osiągnęły niewiele mniej głosów, lecz przyniosło im to zaledwie pojedyncze mandaty do rady gminy. Prawo i Sprawiedliwość uzyskało $13,42 \%$ poparcia i zdobyło 2 mandaty. Dwa lokalne komitety zdobyły po 1 mandacie: Komitet Wyborczy Wyborców Tomasza Wantuły zdo- 
był 12,68\% głosów, natomiast Komitet Wyborczy Wyborców Wojciecha Jagiełły poparło $11,70 \%$ wyborców. Te trzy komitety wyborcze uzyskały łącznie 37,80\% głosów a więc dwa razy więcej niż Platforma Obywatelska. Oczywiście dla osób posiadających choćby podstawową wiedzę na temat konsekwencji stosowania różnych systemów wyborczych, taki stan rzeczy jaki miał miejsce w przedstawionym przykładzie nie jest zaskoczeniem. Jednakże warto podkreślać możliwe skutki zastosowania systemu większościowego $\mathrm{w}$ jednomandatowych okręgach wyborczych, aby uzmysłowić wyborcom i niektórym politykom, że decydując się na wprowadzenie systemu większościowego godzimy się również na jego wady.

Analiza wyników wyborów do rad gmin w 2014 r. pozwala na wskazanie kilku przykładów związanych z jeszcze jedną konsekwencją stosowania systemu większościowego. W wyborach przeprowadzanych według zasady większości może dojść do sytuacji, gdy jeden komitet wyborczy uzyska większe poparcie od swojego konkurenta, a zdobędzie mniej mandatów. Może mieć miejsce również taka sytuacja, że komitety o zbliżonym poparciu wyborczym uzyskują diametralnie różną liczbę mandatów. $\mathrm{Z}$ takimi przypadkami mieliśmy do czynienia także w wyborach samorządowych.

Przykłady dostarcza tym razem kilka gmin. Pierwsza to Oleśnica, w której Komitet Wyborczy Wyborców Razem dla Oleśnicy, którego kandydat wygrał wybory na Prezydenta miasta, zdobył 2987 głosów, co stanowiło 24,98\% poparcia i pozwoliło na uzyskanie 11 mandatów, podczas gdy Komitet Wyborczy Wyborców Porozumienie Samorządowe 2018 poparło 2938, co stanowiło 24,57\% ważnie oddanych głosów, dzięki czemu wprowadził do rady miasta jedynie 5 radnych. Jak widać różnica 49 głosów w popraciu obu komitetów przełożyła się na różnicę aż 6 uzyskanych mandatów. Podobna sytuacja miała miejsce w Chrzanowie. W mieście tym komitet, który wygrał wybory na urząd Prezydenta miasta, mimo że uzyskał 10,65\% poparcia, nie zdołał wprowadzić do rady miasta żadnego radnego. Najwięcej głosów w wyborach uzyskali natomiast kandydaci Platformy Obywatelskiej i Prawa i Sprawiedliwości. PO zdobyła 3977 głosów - 26,72\% poparcia, PiS natomiast 3807 głosów i 25,58\% poparcia. Mimo że oba komitety uzyskały zbliżone poparcie, liczba zdobytych mandatów jest radykalnie odmienna. Platforma Obywatelska uzyskała 12 mandatów i większość w radzie miasta, a Prawo i Sprawiedliwość jedynie 5 , chociaż różnica procentowego poparcia ledwo przekroczyła 1 pkt proc. ważnie oddanych głosów.

Kolejny przykład, zaczerpnięty z Kołobrzegu, różni się trochę od Oleśnicy. W Kołobrzegu wybory na urząd prezydenta wygrał bowiem kandydat Platformy Obywatelskiej, której kandydaci w wyborach do rady miasta uzyskali 4784 głosy, czyli 30,9\% poparcia, co pozwoliło na zdobycie 7 mandatów, podczas gdy komitet konkurenta w drugiej turze 
wyborów prezydenckich, KWW W. Dymckiej „Porozumienie dla Kołobrzegu”, zdobył 5045 głosów, czyli 32,6\% poparcia i uzyskał 11 mandatów. W przypadku Kołobrzegu różnica w liczbie zdobytych mandatów nie była aż tak znacząca, jak w przypadku Oleśnicy, tym niemniej 4 mandaty więcej zdobyte przez lokalny komitet to także spora różnica, szczególnie gdy porównamy procentowe poparcie. Między oboma komitetami różnica $\mathrm{w}$ procentowym poparciu wyniosła 1,7 pkt. proc., podczas gdy różnica w procencie zdobytych mandatów wyniosła $36,6 \%$. Podoba sytuacja wystąpiła także w gminie Jawor. W tym mieście dwa lokalne komitety wyborców osiągnęły zbliżony poziom poparcia. Zwycięski komitet otrzymał 30,72\% głosów i zdobył 11 mandatów, komitet, który był drugi otrzymał 27,37\% głosów, co dało mu 6 mandatów. Różnica procentowa wyniosła 3,35 pkt. proc., natomiast różnica w procencie zdobytych mandatów wyniosła 45,45\%. Zbliżona sytuacja miała miejsce również w Wadowicach. Drugie i trzecie miejsce pod względem uzyskanych głosów zajęły tam dwa lokalne komitety: jeden zdobył 3200 głosów drugi 3211. Ten pierwszy uzyskał 1 mandat a drugi 3. Podobnie wyniki wyborów ułożyły się także w Puławach. W mieście tym kandydaci Platformy Obywatelskiej zdobyli 2 mandaty, natomiast lokalny komitet uzyskał 4 mandaty w radzie miasta. Stało się tak mimo tego, że na kandydatów Platformy zagłosowało więcej wyborców, gdyż 3856, a na lokalny komitet 3741 .

Niezwykle ciekawego przykładu dostarczają wybory do rady gminy w Gryfinie. Wygrał je lokalny komitet wyborców, zdobywając 11 mandatów, dzięki 26,65-proc. poparciu. Gmina ta należy więc do tej grupy gmin, w których zwycięski komitet w wyborach do rady gminy zdobył większość $\mathrm{w}$ radzie przy stosunkowo niskim poparciu wyborczym. Interesujący kazus dotyczy jednakże dwóch innych komitetów konkurujących o mandaty radnych w tym mieście. Otóż komitet Platformy Obywatelskiej, który poparło 5,89\% wyborców uzyskał 2 mandaty, natomiast KWW Rafała Muchy, mimo że zdobył ponad dwukrotnie więcej głosów, uzyskując 13,37\% poparcia, zdołał wprowadzić do rady gminy tylko jednego radnego.

Najciekawsze przykłady miały jednak miejsce w Kłodzku i Brzesku. W Kłodzku dwa lokalne komitety uzyskały zbliżony wynik wyborczy. KWW „Lubię Kłodzko”, którego kandydat wygrał także wybory na urząd prezydenta miasta, zdobył w wyborach do rady miasta 1777 głosów co stanowiło 18,97\% ważnie oddanych głosów. Komitet rywala w drugiej turze wyborów prezydenckich - KWW Bogusława Szpytmy - uzyskał w wyborach do rady miasta 1881 głosów czyli 20,08\% głosów. Mimo wyższego poparcia, komitet ten uzyskał tylko 7 mandatów, podczas gdy komitet „Lubię Kłodzko” zdobył ich 10. Przykład Brzeska jest niemal identyczny jak Kłodzka. Tutaj także lokalny komitet, który odniósł zwy- 
cięstwo w wyborach burmistrza zdobył najwięcej głosów w wyborach do rady gminy - 4969 (38,12\% poparcia) co dało mu 9 mandatów, a mimo to większość $\mathrm{w}$ radzie gminy z 11 mandatami uzyskał komitet Prawa i Sprawiedliwości, na którego kandydatów oddano 4838 głosów $(37,12 \%$ poparcia).

Jednym z oczekiwanych przez zwolenników okręgów jednomandatowych efektów zmiany systemu wyborczego z proporcjonalnego na większościowy miało być umożliwienie kandydowania w wyborach do rad miast i gmin kandydatów niezależnych. Analiza wyborów przeprowadzonych w 2014 r. wskazuje, że cel ten w zasadzie nie został osiągnięty. W 41 na 173 gminach objętych badaniami nie został zgłoszony żaden taki kandydat. W większości z gmin liczba kandydatów niezależnych wahała się między 1 a 4 . Jedynie w 15 gminach zgłosiło swoją kandydaturę więcej niż 4 niezależnych kandydatów. Jednakże warto zauważyć, iż w każdej z tych gmin przynajmniej jeden taki kandydat został wybrany na radnego. Jednocześnie należy podkreślić, że ogólna liczba niezależnych kandydatów samodzielnych nie przekroczyła $10 \%$ wszystkich zgłoszonych kandydatów w wyborach do rad gmin objętych przeprowadzoną analizą.

\begin{tabular}{|l|r|r|}
\hline \multicolumn{1}{|r|}{ Nazwa } & I.s. k. & I.z.m. \\
\hline Gminy & 6 & 1 \\
\hline Legionowo & 6 & 1 \\
Ostrowiec Świętokrzyski & 10 & 4 \\
Starżysko-Kamienna & 5 & 2 \\
Gniezno & 10 & 3 \\
Ostrów Wielkopolski & 7 & 1 \\
Pleszew & 8 & 2 \\
Lębork & 11 & 2 \\
Gryfino & 7 & 3 \\
Kołobrzeg & 5 & 1 \\
Wałcz & 6 & 3 \\
Będzin & 8 & 2 \\
Racibórz & 5 & 2 \\
Zawiercie & 7 & 1 \\
Świdnica & 5 & 2 \\
\hline
\end{tabular}

Tabela 4. Gminy, w których zgłoszono najwięcej niezależnych kandydatów l.s. k. - liczba zgłoszonych niezależnych kandydatów I.z.m - liczba zdobytych mandatów przez niezależnych kandydatów 
W wyborach do rad gmin, które były przedmiotem dokonanych analiz, wystartowało jedynie 336 kandydatów, o których mowa powyżej. $\mathrm{Z}$ tej liczby jedynie 81 zdobyło mandat. Jest to zaskakująco niska liczba; wskazuje ona, że mniej niż $1 / 3$ niezależnych kandydatów zdołała uzyskać poparcie wystarczające do pokonania rywali zgłaszanych przez lokalne komitety wyborców oraz komitety partii politycznych o charakterze ogólnopolskim. Liczba ta wydaje się być tym bardziej niska, że w gminach będących przedmiotem analizy do obsadzenia było łącznie 3682 mandatów. Tak więc niezależni kandydaci aspirowali do objęcia mniej niż 10\% mandatów, o które można się było ubiegać. W efekcie tylko 2,22\% mandatów zostało obsadzonych przez niezależnych kandydatów. Dane te pozwalają na sformułowanie następujących wniosków.

Po pierwsze przekonanie, że wprowadzenie jednomandatowych okręgów wyborczych w wyborach do rad gmin w gminach powyżej 20 tys. mieszkańców przyniesie efekt w postaci pojawienia się w wyborach lokalnych dużej liczby kandydatów na radnych bez zaplecza politycznego wynikającego $\mathrm{z}$ uczestnictwa w życiu publicznym $\mathrm{z}$ ramienia jakiejś partii politycznej o charakterze ogólnokrajowym lub uczestnictwa w działalności lokalnej organizacji polityczno-społecznej, okazało się być chybione. Oczywiście wybory według tego systemu wyborczego zostały przeprowadzone po raz pierwszy, być może w kolejnych elekcjach radnych, gdy obywatele przyzwyczają się do nowych zasad wyboru swych przedstawicieli do rad gmin, zachowania wyborcze ulegną zmianie. Pojawi się większa liczba kandydatów niezależnych i być może lokalne społeczności obdarzą ich większym zaufaniem niż w wyborach przeprowadzonych w 2014 roku. Dotychczasowe obserwacje zgromadzonych danych nie pozwalają na wyciągnięcie takiego wniosku. Zdobycie przez niezależnych kandydatów jedynie 2,22\% mandatów sprawia, że oczekiwanie na jakąśs radykalną zmianę tego stanu rzeczy w kolejnych wyborach wydaje się być bezpodstawne. Nadzieja, że nowy system wyborczy pozwoli lokalnym liderom na uzyskanie mandatów radnych bez konieczności uczestnictwa w szerszym projekcie politycznym okazała się płonna. Rzecz jasna pewna część liderów lokalnych społeczności znalazła się w radach swych miast lub gmin, lecz jako kandydaci rozmaitych komitetów wyborczych, które wystawiały kandydatów w większej liczbie okręgów wyborczych. Jednakże można przypuszczać, że w ich przypadku odnieśliby oni sukces wyborczy także w wyborach przeprowadzanych według wcześniejszych reguł, tzn. według zasady proporcjonalności. Zgromadzone dane pozwalają spojrzeć na analizowaną kwestię również z punktu widzenia geograficznego zróżnicowania postaw wyborczych.

Przeprowadzone badania pozwalają także wskazać na pewne geograficzne zróżnicowanie w liczbie zgłaszanych kandydatów niezależnych. Wprawdzie wskazanie przyczyn tych prawidłowości jest zadaniem dla 
socjologów i politologów, a nie dla prawnika, tym niemniej jako ciekawostkę można wskazać efekty przeprowadzonych analiz. Otóż najwięcej niezależnych kandydatów wystartowało w województwach: mazowieckim (45) wielkopolskim (53) i zachodniopomorskim (33). W tych też województwach najwięcej mandatów zdobyli kandydaci niezależni: Mazowieckie 10, Wielkopolskie 13, Zachodniopomorskie 12. Najmniej niezależnych kandydatów zarejestrowało swoje kandydatury w województwach: podlaskim (3), lubuskim (4), warmińsko-mazurskim (5) i kujawsko-pomorskim (7). W województwie warmińsko-mazurskim z 5 kandydatów aż 3 zdobyło mandat, co jest najlepszym wynikiem procentowym w kraju. W przypadku trzech pozostałych województw tylko jeden kandydat niezależny w każdym z nich dostał się do rady miasta lub gminy.

\begin{tabular}{|c|c|c|c|c|c|c|c|c|}
\hline Województwo & Gmina & $\begin{array}{l}\text { liczba } \\
\text { komit. }\end{array}$ & $\begin{array}{c}\text { komit. } \\
\text { ogól. }\end{array}$ & $\begin{array}{l}\text { komit. } \\
\text { loklane }\end{array}$ & \begin{tabular}{|l|} 
kand. \\
niezal.
\end{tabular} & $\begin{array}{l}\text { mand. } \\
\text { niezal. }\end{array}$ & $\begin{array}{c}\text { mand. } \\
\text { ogól. }\end{array}$ & $\begin{array}{l}\text { mand. } \\
\text { lokal. }\end{array}$ \\
\hline \multirow{16}{*}{ Dolnośląskie } & Bolestawiec & 7 & 3 & 4 & 0 & 0 & 1 & 20 \\
\hline & Głogów & 11 & 1 & 9 & 1 & 0 & 0 & 23 \\
\hline & Jawor & 6 & 0 & 5 & 1 & 0 & 0 & 21 \\
\hline & Kamienna Góra & 9 & 2 & 7 & 0 & 0 & 5 & 16 \\
\hline & Kłodzko & 13 & 2 & 8 & 3 & 1 & 1 & 20 \\
\hline & Lubań & 9 & 3 & 5 & 1 & 1 & 2 & 19 \\
\hline & Lubin & 12 & 2 & 6 & 4 & 1 & 1 & 22 \\
\hline & Nowa Ruda & 8 & 2 & 6 & 0 & 0 & 4 & 17 \\
\hline & Oleśnica & 9 & 3 & 5 & 1 & 0 & 4 & 17 \\
\hline & Oława & 6 & 3 & 3 & 0 & 0 & 13 & 8 \\
\hline & Strzelin & 8 & 2 & 6 & 0 & 0 & 1 & 20 \\
\hline & Świdnica & 18 & 4 & 9 & 5 & 2 & 10 & 13 \\
\hline & Trzebnica & 7 & 1 & 3 & 3 & 1 & 0 & 21 \\
\hline & Wołów & 10 & 1 & 6 & 3 & 0 & 1 & 20 \\
\hline & Ząbkowice śl. & 10 & 2 & 8 & 0 & 0 & 1 & 20 \\
\hline & Zgorzelec & 10 & 1 & 6 & 3 & 0 & 1 & 20 \\
\hline \multirow{6}{*}{$\begin{array}{l}\text { Kujawsko-po- } \\
\text { morskie }\end{array}$} & Brodnica & 9 & 3 & 5 & 1 & 0 & 6 & 15 \\
\hline & Inowroctaw & 8 & 2 & 3 & 3 & 1 & 6 & 17 \\
\hline & Nakło & 6 & 3 & 2 & 1 & 0 & 10 & 11 \\
\hline & Mogilno & 6 & 4 & 1 & 1 & 0 & 19 & 2 \\
\hline & Świecie & 7 & 4 & 3 & 0 & 0 & 6 & 15 \\
\hline & Żnin & 13 & 3 & 8 & 2 & 0 & 4 & 17 \\
\hline \multirow{2}{*}{ Lubelskie } & Bitgoraj & 10 & 3 & 7 & 0 & 0 & 3 & 18 \\
\hline & Kraśnik & 11 & 3 & 7 & 1 & 0 & 17 & 4 \\
\hline
\end{tabular}




\begin{tabular}{|c|c|c|c|c|c|c|c|c|}
\hline Województwo & Gmina & $\begin{array}{l}\text { liczba } \\
\text { komit. }\end{array}$ & $\begin{array}{c}\text { komit. } \\
\text { ogól. }\end{array}$ & \begin{tabular}{|l|} 
komit. \\
loklane \\
\end{tabular} & $\begin{array}{l}\text { kand. } \\
\text { niezal. }\end{array}$ & \begin{tabular}{|l} 
mand. \\
niezal.
\end{tabular} & $\begin{array}{c}\text { mand. } \\
\text { ogól. }\end{array}$ & $\begin{array}{l}\text { mand. } \\
\text { lokal. }\end{array}$ \\
\hline \multirow{7}{*}{ Lubelskie } & Lubartów & 15 & 2 & 9 & 4 & 2 & 7 & 14 \\
\hline & Łęczna & 9 & 3 & 3 & 3 & 0 & 4 & 17 \\
\hline & Łuków & 10 & 4 & 6 & 0 & 0 & 16 & 5 \\
\hline & Puławy & 7 & 3 & 2 & 2 & 0 & 16 & 5 \\
\hline & Ryki & 7 & 3 & 4 & 0 & 0 & 11 & 10 \\
\hline & Świdnik & 4 & 1 & 3 & 0 & 0 & 1 & 20 \\
\hline & $\begin{array}{l}\text { Tomaszów Lu- } \\
\text { belski }\end{array}$ & 11 & 4 & 5 & 2 & 0 & 18 & 3 \\
\hline \multirow{4}{*}{ Lubuskie } & Nowa Sól & 9 & 4 & 3 & 2 & 0 & 0 & 21 \\
\hline & Wschowa & 8 & 2 & 5 & 1 & 0 & 1 & 20 \\
\hline & Żagań & 11 & 3 & 7 & 1 & 1 & 5 & 16 \\
\hline & Żary & 10 & 3 & 7 & 0 & 0 & 8 & 13 \\
\hline \multirow{12}{*}{ Łódzkie } & Bełchatów & 10 & 3 & 7 & 0 & 0 & 15 & 8 \\
\hline & Łask & 10 & 4 & & 1 & 1 & 6 & 15 \\
\hline & Łowicz & 13 & 5 & 7 & 1 & 0 & 12 & 9 \\
\hline & Kutno & 10 & 4 & 5 & 1 & 0 & 0 & 21 \\
\hline & Opoczno & 12 & 3 & 6 & 3 & 1 & 3 & 18 \\
\hline & Pabianice & 10 & 3 & 4 & 3 & 0 & 23 & 0 \\
\hline & Radomsko & 9 & 4 & 3 & 2 & 0 & 15 & 6 \\
\hline & Sieradz & 10 & 4 & 4 & 2 & 0 & 12 & 9 \\
\hline & $\begin{array}{l}\text { Tomaszów Mazo- } \\
\text { wiecki }\end{array}$ & 8 & 4 & 3 & 1 & 0 & 22 & 1 \\
\hline & Wieluń & 10 & 4 & 5 & 1 & 0 & 7 & 14 \\
\hline & Zduńska Wola & 13 & 6 & 7 & 2 & 1 & 11 & 10 \\
\hline & Zgierz & 14 & 4 & 8 & 2 & 0 & 11 & 10 \\
\hline \multirow{11}{*}{ Małopolskie } & Bochnia & 10 & 3 & 7 & 0 & 0 & 9 & 12 \\
\hline & Brzesko & 10 & 3 & 5 & 2 & 0 & 12 & 9 \\
\hline & Chrzanów & 7 & 4 & 2 & 1 & 0 & 17 & 4 \\
\hline & $\begin{array}{l}\text { Dąbrowa Tar- } \\
\text { nowska }\end{array}$ & 9 & 2 & 6 & 1 & 0 & 8 & 13 \\
\hline & Gorlice & 9 & 3 & 5 & 1 & 0 & 5 & 16 \\
\hline & Nowy Targ & 12 & 2 & 7 & 3 & 0 & 3 & 18 \\
\hline & Myślenice & 9 & 2 & 3 & 4 & 1 & 8 & 13 \\
\hline & Olkusz & 12 & 3 & 7 & 2 & 0 & 15 & 6 \\
\hline & Oświęcim & 11 & 4 & 4 & 3 & 1 & 17 & 4 \\
\hline & Wadowice & 7 & 4 & 3 & 0 & 0 & 2 & 19 \\
\hline & Zakopane & 9 & 1 & 7 & 1 & 1 & 4 & 17 \\
\hline
\end{tabular}




\begin{tabular}{|c|c|c|c|c|c|c|c|c|}
\hline Województwo & Gmina & $\begin{array}{l}\text { liczba } \\
\text { komit. }\end{array}$ & $\begin{array}{c}\text { komit. } \\
\text { ogól. }\end{array}$ & $\begin{array}{l}\text { komit. } \\
\text { loklane }\end{array}$ & $\begin{array}{l}\text { kand. } \\
\text { niezal. }\end{array}$ & $\begin{array}{l}\text { mand. } \\
\text { niezal. }\end{array}$ & $\begin{array}{c}\text { mand. } \\
\text { ogól. }\end{array}$ & $\begin{array}{l}\text { mand. } \\
\text { lokal. }\end{array}$ \\
\hline \multirow{18}{*}{ Mazowieckie } & Ciechanów & 11 & 3 & 5 & 3 & 1 & 16 & 5 \\
\hline & $\begin{array}{l}\text { Grodzisk Mazo- } \\
\text { wiecki }\end{array}$ & 9 & 1 & 6 & 2 & 0 & 0 & 21 \\
\hline & Grójec & 8 & 2 & 6 & 0 & 0 & 0 & 21 \\
\hline & Legionowo & 16 & 2 & 8 & 6 & 1 & 1 & 22 \\
\hline & Kozienice & 13 & 3 & 4 & 6 & 1 & 7 & 14 \\
\hline & $\begin{array}{l}\text { Nowy Dwór } \\
\text { Mazowiecki }\end{array}$ & 10 & 1 & 5 & 4 & 0 & 0 & 21 \\
\hline & Mińsk Mazowiecki & 8 & 3 & 4 & 1 & 0 & 18 & 3 \\
\hline & Mława & 11 & 3 & 5 & 3 & 1 & 3 & 18 \\
\hline & $\begin{array}{l}\text { Ostrów Mazo- } \\
\text { wiecka }\end{array}$ & 10 & 3 & 5 & 2 & 1 & 5 & 16 \\
\hline & Otwock & 17 & 5 & 11 & 1 & 1 & 12 & 9 \\
\hline & Piaseczno & 14 & 3 & 10 & 1 & 0 & 14 & 9 \\
\hline & Płońsk & 9 & 3 & 5 & 2 & 1 & 4 & 17 \\
\hline & Pruszków & 11 & 3 & 5 & 3 & 1 & 10 & 13 \\
\hline & Puttusk & 10 & 2 & 5 & 3 & 1 & 10 & 11 \\
\hline & Sochaczew & 7 & 2 & 5 & 0 & 0 & 5 & 16 \\
\hline & Wołomin & 9 & 2 & 5 & 2 & 0 & 0 & 23 \\
\hline & Wyszków & 13 & 3 & 6 & 4 & 1 & 3 & 18 \\
\hline & Żyrardów & 16 & 2 & 10 & 2 & 0 & 12 & 9 \\
\hline \multirow{9}{*}{ Opolskie } & Brzeg & 10 & 4 & 5 & 1 & 0 & 14 & 7 \\
\hline & Głubczyce & 10 & 3 & 4 & 3 & 0 & 1 & 20 \\
\hline & Kędzierzyn-Koźle & 15 & 4 & 9 & 2 & 2 & 15 & 8 \\
\hline & Kluczbork & 9 & 4 & 4 & 1 & 0 & 3 & 18 \\
\hline & Krapkowice & 8 & 2 & 6 & 0 & 0 & 0 & 21 \\
\hline & Namysłów & 14 & 4 & 6 & 4 & 1 & 12 & 9 \\
\hline & Nysa & 15 & 4 & 7 & 4 & 3 & 11 & 10 \\
\hline & Prudnik & 9 & 4 & 5 & 0 & 0 & 10 & 11 \\
\hline & Strzelce Opolskie & 9 & 4 & 5 & 0 & 0 & 3 & 18 \\
\hline \multirow{8}{*}{ Podkarpackie } & Brzozów & 10 & 3 & 4 & 3 & 0 & 6 & 15 \\
\hline & Dębica & 10 & 3 & 7 & 0 & 0 & 19 & 2 \\
\hline & Jarosław & 16 & 5 & 7 & 4 & 1 & 14 & 7 \\
\hline & Jasto & 7 & 3 & 4 & 0 & 0 & 11 & 10 \\
\hline & Kolbuszowa & 7 & 3 & 3 & 1 & 0 & 9 & 12 \\
\hline & Nisko & 9 & 1 & 5 & 3 & 1 & 3 & 18 \\
\hline & Mielec & 11 & 4 & 6 & 1 & 0 & 13 & 8 \\
\hline & Sanok & 11 & 3 & 7 & 1 & 1 & 10 & 11 \\
\hline
\end{tabular}




\begin{tabular}{|c|c|c|c|c|c|c|c|c|}
\hline Województwo & Gmina & $\begin{array}{l}\text { liczba } \\
\text { komit. }\end{array}$ & $\begin{array}{c}\text { komit. } \\
\text { ogól. }\end{array}$ & $\begin{array}{l}\text { komit. } \\
\text { loklane }\end{array}$ & $\begin{array}{l}\text { kand. } \\
\text { niezal. }\end{array}$ & $\begin{array}{l}\text { mand. } \\
\text { niezal. }\end{array}$ & $\begin{array}{l}\text { mand. } \\
\text { ogól. }\end{array}$ & $\begin{array}{l}\text { mand. } \\
\text { lokal. }\end{array}$ \\
\hline & Sędziszów & 9 & 1 & 5 & 3 & 1 & 4 & 17 \\
\hline & Stalowa Wola & 9 & 2 & 5 & 2 & 0 & 19 & 4 \\
\hline & Strzyżów & 7 & 3 & 3 & 1 & 0 & 0 & 21 \\
\hline \multirow{6}{*}{ Podlaskie } & Augustów & 8 & 2 & 6 & 0 & 0 & 9 & 12 \\
\hline & Bielsk Podlaski & 7 & 2 & 5 & 0 & 0 & 5 & 16 \\
\hline & Grajewo & 10 & 5 & 4 & 1 & 0 & 5 & 16 \\
\hline & Hajnówka & 4 & 2 & 2 & 0 & 0 & 7 & 14 \\
\hline & Sokółka & 8 & 3 & 5 & 0 & 0 & 10 & 11 \\
\hline & Zambrów & 11 & 3 & 6 & 2 & 1 & 6 & 15 \\
\hline \multirow{10}{*}{ Pomorskie } & Bytów & 6 & 2 & 3 & 1 & 0 & 15 & 6 \\
\hline & Chojnice & 7 & 3 & 3 & 1 & 0 & 2 & 19 \\
\hline & Kartuzy & 9 & 2 & 7 & 0 & 0 & 2 & 19 \\
\hline & Kościerzyna & 10 & 3 & 6 & 1 & 0 & 4 & 17 \\
\hline & Kwidzyń & 5 & 3 & 2 & 0 & 0 & 19 & 2 \\
\hline & Lębork & 19 & 1 & 7 & 11 & 2 & 1 & 20 \\
\hline & Malbork & 8 & 2 & 4 & 2 & 1 & 4 & 17 \\
\hline & \begin{tabular}{|l|} 
Starogard \\
Gdański \\
\end{tabular} & 6 & 2 & 3 & 1 & 0 & 14 & 7 \\
\hline & Tczew & 11 & 3 & 6 & 2 & 0 & 9 & 14 \\
\hline & Wejherowo & 7 & 2 & 4 & 1 & 0 & 11 & 10 \\
\hline \multirow{13}{*}{ Śląskie } & Będzin & 16 & 2 & 6 & 8 & 2 & 5 & 18 \\
\hline & Cieszyn & 9 & 3 & 5 & 1 & 0 & 2 & 19 \\
\hline & Kłobuck & 11 & 5 & 5 & 1 & 0 & 5 & 16 \\
\hline & Knurów & 12 & 2 & 8 & 2 & 0 & 2 & 19 \\
\hline & Lubliniec & 2 & 0 & 2 & 0 & 0 & 0 & 21 \\
\hline & Łaziska Górne & 7 & 1 & 5 & 1 & 0 & 0 & 21 \\
\hline & Myszków & 10 & 4 & 6 & 0 & 0 & 13 & 8 \\
\hline & Pszczyna & 16 & 3 & 9 & 4 & 3 & 3 & 18 \\
\hline & Racibórz & 10 & 0 & 5 & 5 & 2 & 0 & 23 \\
\hline & Tarnowskie Góry & 6 & 3 & 3 & 0 & 0 & 0 & 23 \\
\hline & Wodzisław & 10 & 3 & 5 & 2 & 0 & 1 & 20 \\
\hline & Zawiercie & 18 & 5 & 6 & 7 & 1 & 13 & 10 \\
\hline & Żywiec & 9 & 3 & 5 & 1 & 0 & 1 & 20 \\
\hline \multirow{4}{*}{ Świętokrzyskie } & Busko-Zdrój & 9 & 4 & 5 & 0 & 0 & 2 & 19 \\
\hline & Jędrzejów & 8 & 2 & 5 & 1 & 0 & 6 & 15 \\
\hline & Końskie & 10 & 4 & 5 & 1 & 0 & 13 & 8 \\
\hline & $\begin{array}{l}\text { Ostrowiec Świę- } \\
\text { tokrzyski }\end{array}$ & 14 & 3 & 5 & 6 & 1 & 10 & 13 \\
\hline
\end{tabular}




\begin{tabular}{|c|c|c|c|c|c|c|c|c|}
\hline Województwo & Gmina & $\begin{array}{l}\text { liczba } \\
\text { komit. }\end{array}$ & $\begin{array}{c}\text { komit. } \\
\text { ogól. }\end{array}$ & \begin{tabular}{|l|} 
komit. \\
loklane
\end{tabular} & $\begin{array}{l}\text { kand. } \\
\text { niezal. }\end{array}$ & $\begin{array}{l}\text { mand. } \\
\text { niezal. }\end{array}$ & $\begin{array}{l}\text { mand. } \\
\text { ogól. }\end{array}$ & $\begin{array}{l}\text { mand. } \\
\text { lokal. }\end{array}$ \\
\hline & Pińczów & 8 & 3 & 3 & 2 & 0 & 10 & 11 \\
\hline & Sandomierz & 9 & 3 & 5 & 1 & 0 & 6 & 15 \\
\hline & Skarżysko & 18 & 4 & 4 & 10 & 4 & 7 & 14 \\
\hline & Starachowice & 10 & 4 & 6 & 0 & 0 & 12 & 11 \\
\hline & Staszów & 14 & 4 & 5 & 5 & 2 & 7 & 14 \\
\hline & Włoszczowa & 11 & 6 & 5 & 0 & 0 & 6 & 15 \\
\hline \multirow{11}{*}{$\begin{array}{l}\text { Warmińsko- } \\
\text {-mazurskie }\end{array}$} & Bartoszyce & 6 & 3 & 3 & 0 & 0 & 7 & 14 \\
\hline & Działdowo & 9 & 1 & 7 & 1 & 1 & 2 & 19 \\
\hline & Ełk & 11 & 4 & 6 & 1 & 0 & 9 & 14 \\
\hline & Giżycko & 6 & 2 & 4 & 0 & 0 & 0 & 21 \\
\hline & Iława & 8 & 3 & 5 & 0 & 0 & 11 & 10 \\
\hline & Kętrzyn & 7 & 3 & 4 & 0 & 0 & 7 & 14 \\
\hline & Mrągowo & 11 & 3 & 7 & 1 & 1 & 5 & 16 \\
\hline & Nidzica & 5 & 2 & 3 & 0 & 0 & 9 & 12 \\
\hline & Ostróda & 8 & 2 & 5 & 1 & 1 & 4 & 17 \\
\hline & Pisz & 9 & 3 & 5 & 1 & 0 & 5 & 16 \\
\hline & Szczytno & 11 & 4 & 7 & 0 & 0 & 9 & 12 \\
\hline \multirow{16}{*}{ Wielkopolskie } & Gostynin & 6 & 0 & 3 & 3 & 1 & 0 & 21 \\
\hline & Gniezno & 18 & 5 & 3 & 10 & 3 & 14 & 10 \\
\hline & Jarocin & 5 & 2 & 3 & 0 & 0 & 4 & 17 \\
\hline & Koło & 10 & 3 & 4 & 3 & 0 & 7 & 14 \\
\hline & Kościan & 8 & 3 & 3 & 2 & 1 & 0 & 21 \\
\hline & Nowy Tomyśl & 8 & 3 & 5 & 0 & 0 & 2 & 19 \\
\hline & Oborniki & 8 & 1 & 4 & 3 & 0 & 0 & 21 \\
\hline & $\begin{array}{l}\text { Ostrów Wielko- } \\
\text { polski }\end{array}$ & 17 & 3 & 7 & 7 & 1 & 15 & 8 \\
\hline & Ostrzeszów & 6 & 3 & 3 & 0 & 0 & 14 & 7 \\
\hline & Piła & 11 & 3 & 4 & 4 & 0 & 21 & 2 \\
\hline & Pleszew & 13 & 2 & 3 & 8 & 2 & 2 & 19 \\
\hline & Rawicz & 11 & 3 & 4 & 4 & 0 & 6 & 15 \\
\hline & $\begin{array}{l}\text { Środa Wielkopol- } \\
\text { ska. }\end{array}$ & 6 & 2 & 3 & 1 & 1 & 3 & 18 \\
\hline & Turek & 14 & 5 & 5 & 4 & 1 & 7 & 14 \\
\hline & Wolsztyn & 10 & 3 & 4 & 3 & 1 & 6 & 15 \\
\hline & Września & 7 & 3 & 3 & 1 & 1 & 0 & 21 \\
\hline \multirow{3}{*}{$\begin{array}{l}\text { Zachodniopo- } \\
\text { morskie }\end{array}$} & Białogard & 6 & 2 & 4 & 0 & 0 & 1 & 20 \\
\hline & Choszczno & 9 & 2 & 4 & 3 & 1 & 0 & 21 \\
\hline & Goleniów & 16 & 4 & 8 & 4 & 1 & 10 & 11 \\
\hline
\end{tabular}




\begin{tabular}{|l|l|c|c|c|c|c|c|c|}
\hline Województwo & \multicolumn{1}{|c|}{ Gmina } & $\begin{array}{c}\text { liczba } \\
\text { komit. }\end{array}$ & $\begin{array}{c}\text { komit. } \\
\text { ogól. }\end{array}$ & $\begin{array}{c}\text { komit. } \\
\text { loklane }\end{array}$ & $\begin{array}{c}\text { kand. } \\
\text { niezal. }\end{array}$ & $\begin{array}{c}\text { mand. } \\
\text { niezal. }\end{array}$ & $\begin{array}{c}\text { mand. } \\
\text { ogól. }\end{array}$ & $\begin{array}{c}\text { mand. } \\
\text { lokal. }\end{array}$ \\
\hline \multirow{5}{*}{$\begin{array}{l}\text { Zachodniopo- } \\
\text { morskie }\end{array}$} & Gryfice & 12 & 3 & 7 & 2 & 1 & 4 & 17 \\
\cline { 2 - 10 } & Gryfino & 19 & 3 & 9 & 7 & 3 & 2 & 19 \\
\cline { 2 - 10 } & Kołobrzeg & 13 & 2 & 6 & 5 & 1 & 7 & 14 \\
\cline { 2 - 10 } & Myślibórz & 10 & 4 & 5 & 1 & 0 & 10 & 11 \\
\cline { 2 - 10 } & Police & 11 & 5 & 5 & 1 & 0 & 3 & 18 \\
\cline { 2 - 10 } & $\begin{array}{l}\text { Starogard Szcze- } \\
\text { ciński }\end{array}$ & 11 & 3 & 6 & 2 & 1 & 6 & 15 \\
\cline { 2 - 10 } & Szczecinek & 7 & 2 & 3 & 2 & 1 & 14 & 7 \\
\cline { 2 - 10 } & Wałcz & 15 & 1 & 8 & 6 & 3 & 0 & 21 \\
\hline
\end{tabular}

Tabela 5. Liczba zgłoszonych komitetów w poszczególnych gminach, w tym komitetów ogólnokrajowych, lokalnych i kandydatów niezależnych oraz liczba zdobytych mandatów przez poszczególne kategorie podmiotów uczestniczących w wyborach

Podsumowując wyniki przeprowadzonych analiz, można sformułować następujące wnioski. Po pierwsze, przeprowadzenie wyborów w jednomandatowych okręgach wyborczych nie zaowocowało dużą liczbą kandydatów niezależnych. Po drugie, kandydaci ci zdobyli stosunkowo niewielką liczbę mandatów. Po trzecie, większościowy system wyborczy w największym stopniu, spośród zasad podziału mandatów obowiązujących w Polsce w wyborach samorządowych, wpłynął na stworzenie stabilnych większości $w$ radach miast i gmin. Nawet blokowanie list wyborczych zastosowane w wyborach w 2006 r. nie przyniosło tak wyraźnych korzyści dla komitetów wyborczych, które zdobyły największe poparcie ${ }^{10}$. Po czwarte, $\mathrm{w}$ wyborach samorządowych na niespotykaną do tej pory skalę nastąpiło umocnienie pozycji w radach miasta komitetów wyborczych, które odniosły także sukces w wyborach prezydentów i burmistrzów miast. Po piąte, w żadnych dotychczasowych wyborach, w tak wielu miastach, jeden komitet wyborczy nie uzyskał większości w radzie miasta lub gminy. Po szóste, po raz pierwszy w wyborach samorządowych doszło do sytuacji, gdy jeden komitet wyborczy zdobył ponad $90 \%$ mandatów w radzie gminy.

Jest zbyt wcześnie na kompleksową ocenę przyjętego w wyborach samorządowych systemu wyborczego. Być może w kolejnych wyborach zachowania wyborcze ulegną zmianie. Na ostateczny werdykt przyjdzie czas po kolejnych wyborach, które odpowiedzą na pytanie, czy dostrzeżo-

$10 \mathrm{Na}$ temat skutków zastosowania blokowania list wyborczych w wyborach w 2006 r. Patrz: M. Rakowski, Blokowanie list w wyborach samorządowych - nowelizacja ordynacji wyborczej i jej skutki na przykładzie wyborów do rad wojewódzkich, „Studia Wyborcze", Tom III/2007, s. 7-35. 
ne tendencje ulegną utrwaleniu. Jednakże opisane zjawiska są moim zdaniem niepokojące. Rozstrzygnięcia wyborcze jakie miały miejsce w wielu gminach w wyborach w 2014 r. mogą doprowadzić do tego, że zamiast kilku inicjatyw lokalnych i niezależnych kandydatów w kolejnych wyborach do rywalizacji wyborczej przystępować będą dwa lub trzy komitety wyborcze, gdyż skłaniać będzie do tego logika systemu większościowego.

Każdy z występujących współcześnie systemów wyborczych posiada określone wady i zalety. Kwestie te są bogato opisane w literaturze przedmiotu $^{11}$. Przyjęcie określonego systemu wyborczego niesie ze sobą rozmaite konsekwencje dla kształtu wybieranego organu a co za tym idzie dla sfery praktycznej sprawowania władzy. Różne są także konsekwencje dla realizacji poszczególnych funkcji wyborów. W literaturze przedmiotu poświęcono tej kwestii wiele miejsca ${ }^{12}$. Dokonując wyboru określonego systemu wyborczego należy zdać sobie sprawę ze skutków jego stosowania, aby osiągnąć zamierzone cele. Należy więc z uwagą przyjrzeć się wnioskom płynącym z dotychczasowych doświadczeń tak, aby optymalnie skonstruować w przyszłości system w wyborach do jednostek samorządu terytorialnego.

11 B. Banaszak, Porównawcze prawo konstytucyjne wspótczesnych państw demokratycznych, Kraków 2004, s. 372-385; G. Bingham Powell Jr., Wybory jako narzędzie demokracji. Koncepcje większościowe i proporcjonalne, Warszawa 2006; D. Nohlen, Prawo wyborcze $i$ system partyjny, o teorii systemów wyborczych, Warszawa 2004; A. Żukowski, Systemy wyborcze. Wprowadzenie, Olsztyn 1999.

12 G. Bingham Powell Jr., op. cit., s. 53-137; D. Nohlen, op. cit., s. 143-150. 


\section{Bibliografia}

Bata P., Problematyka prekampanii w wyborach samorzadowych na szczeblu gminy, „Przegląd Sejmowy” 2015, nr 3 (128).

Banaszak B., Porównawcze prawo konstytucyjne współczesnych państw demokratycznych, Kraków 2004.

Bingham Powell G. Jr., Wybory jako narzędzie demokracji. Koncepcje większościowe i proporcjonalne, Warszawa 2006.

Cebula A., Materialna równość wyborów do rad gmin niebędacych miastami na prawach powiatu, „Państwo i Prawo" 2015, nr 2.

Kodeks Dobrej Praktyki w Sprawach Wyborczych. Wytyczne i Raport wyjaśniajacy, przyjęte przez Europejską Komisję dla Demokracji przez Prawo (Komisję Wenecką) Rady Europy w lipcu 2002 r., www.pkw.gov.pl (dostęp 12.10.2015 r.).

Kryszeń G., Problematyka zgłaszania kandydatów w świetle kodeksu wy- borczego, [w:] Kodeks wyborczy. Wstępna ocena, red. Skotnicki K., Warszawa 2011.

Nohlen D., Prawo wyborcze i system partyjny, o teorii systemów wyborczych, Warszawa 2004.

Rakowski M., Blokowanie list w wyborach samorzadowych - nowelizacja ordynacji wyborczej i jej skutki na przykładzie wyborów do rad wojewódzkich, „Studia Wyborcze”, Tom III/2007.

Składowski K., Zasada równości wyborów a wybory do Senatu w kodeksie wyborczym, [w:] Kodeks wyborczy. Wstępna ocena, red. Skotnicki K., Warszawa 2011.

Szymanek J., Prawna regulacja komitetów wyborczych w kodeksie wyborczym, [w:] Kodeks wyborczy. Wstępna ocena, red. Skotnicki K., Warszawa 2011.

Żukowski A., Systemy wyborcze. Wprowadzenie, Olsztyn 1999. 